\title{
Environmental safety in the framework of sustainable development of the region (on the example of the Siberian Federal District)
}

\author{
E.A. Zhidkova ${ }^{1, *}$, and I.A. Dymova ${ }^{2}$ \\ ${ }^{1}$ Kemerovo State University, Kemerovo, Russia \\ ${ }^{2}$ T. F. Gorbachev Kuzbass State Technical University
}

\begin{abstract}
A statistical analysis of public opinion on environmental safety issues was carried out. The Siberian Federal District was chosen as the object of the study. Special attention is paid to the development of environmental safety in the Krasnoyarsk Territory and the Kemerovo Region (Kuzbass). The main criterion for determining the coordinates of "critical" points was the results of a social survey conducted by the Special Communications and Information Service of the Federal Security Service of Russia. The reasons for the negative impact on the state of the environment of the Siberian Federal District are revealed. It is established that when preventive measures are not so effective to maintain a high level of environmental safety, the compensation of environmental damage can pass through the organization of the institute of environmental insurance.
\end{abstract}

\section{Introduction}

Theory and practice of sustainable development in Russia is associated with indicators of economic growth. Sustainable development is interpreted in a broader aspect at the international level and is associated not only with the economic phenomena implementation, but also with environmental and social processes. Currently, due to the ongoing scientific and technological breakthroughs, there is a limit to the use of the Russian raw-materials export model of development. On the one hand, there is a decrease in resources of producing fields, leading to a decline in economic growth, and, on the other hand, the expansion of exploration and extraction of minerals causes damage to the environment, reducing environmental safety level.

\section{Methods and Materials}

Regulations affecting development, ecology, and economic security were adopted contiguously in the spring of 2017. Thus, on January 24, 2017, the President of the Russian Federation approved a list of instructions based on the results of the State Council meeting "On the Environmental Development of the Russian Federation for Future Generations", which main purpose is Russia's transition to a model of environmentally sustainable

* Corresponding author: 291154@mail.ru 
development. Decrees of the President of the Russian Federation No. 176 dated April 19, 2017, and No. 208 dated May 13, 2017, the Environmental Security Strategy of the Russian Federation for the period until 2025 and the Economic Security Strategy of the Russian Federation for the period until 2030, were approved, respectively.

These documents determine that environmental security is an integral part of the country's national security, while the economic security strategy is implemented in order to comply with national interests and priorities. There is no doubt that the problems of environmental and economic security are interdependent and require interrelated solutions. Among the main tasks stipulated in the "Economic Security Strategy of the Russian Federation for the period until 2030" is the need to observe measures to ensure a favorable environment and increase the level of environmental security.

According to experts' estimates, the deterioration of environmental quality leads to an annual decrease in the gross domestic product by $4-6 \%$ [1]. Therefore, economic security state is directly affected by global climate change [2]. Among other threats to economic security caused by environmental problems, challenges associated with growth of costs as part of the requirements of production and consumption environmental standards, as well as with the establishment of overestimated rules in environmental security are noted.

\section{Results and Discussion}

Ecological condition assessment of the Russian Federation showed that $15 \%$ of land area of Russia has the status of disadvantaged territories according to ecological parameters. Therewith, 17.1 million people live in cities with high and very high levels of air pollution. Thus, $17 \%$ of Russia's urban population breathes industrial waste, putting their lives at risk. Therewith, one third of the Russian Federation territory is located in places prone to natural and man-made disasters, which may involve more than 15 million people.

Signals Dispatch and Information Service of the Federal Protection Service of Russia monitors public opinion on environmental safety issues. 47,772 people from 85 regions of Russia participated in the sociological survey conducted from October 31, 2016 to November 18, 2016. According to the results of this survey it was found that the residents of the Siberian Federal District (SFD) see the greatest threat to environmental safety of their region, primarily in air pollution, forest conditions, water quality and waste accumulation.

The highest percentage of respondents in six of the ten SFD regions, when asked: "What in the environmental situation of the subject of your residence worries you the most?", answered - atmospheric air pollution. This is the opinion of respondents of $72.7 \%$ of the Omsk Region, $67.4 \%$ of the Krasnoyarsk Region, $61.1 \%$ of the Kemerovo Region (Kuzbass), $56.5 \%$ of the Republic of Khakassia, $47.1 \%$ of the Novosibirsk Region and $41.1 \%$ of the Tuva Republic [4]. And this is not accidental, because the list of cities of the Russian Federation with registered cases of high air pollution in 2019 included SFD cities as Barnaul, Biysk, Irkutsk, Kemerovo, Krasnoyarsk, Novokuznetsk, and Novosibirsk. Therewith, the highest values of air emissions of pollutants from stationary sources were noted in Achinsk of Krasnoyarsk region, where this indicator was 2,699.8 thousand tons, in Novokuznetsk urban district of Kemerovo Region (Kuzbass) was 1893.7 thousand tons, in the capital of Omsk Region was 1,736.3 thousand tons [3]. But it shall be noted that atmospheric air pollution is influenced by natural and social factors. For example, in Krasnoyarsk in 2019, compared with the previous year 2018, the detected volume of harmful substances concentration was lower by: $12 \%$ suspended solids; $36 \%$ nitrogen oxide; $30 \%$ phenol; $50 \%$ hydrogen fluoride; $13 \%$ formaldehyde; $40 \%$ benz(a)pyrene [3]. First of all, the improvement of atmospheric air was influenced by meteorological conditions observed in Krasnoyarsk in 2019 and contributing to the atmospheric air 
purification. It shall be noted that in 2019 Krasnoyarsk became the venue of the 29th Winter Universiade, which was the reason for a number of activities aimed at improving the environmental situation in the city. For example, coal, which is widely used for heating homes in the private sector in winter, was replaced by alternative fuels. Kemerovo Region (Kuzbass) ranks 2nd in terms of environmental pollution in the SFD after the Krasnoyarsk Region. Therewith, the largest share in the total volume of environmental pollution falls on enterprises of coal mining, metallurgical and chemical industries. Climate and geographical location peculiarities of Kemerovo Region (Kuzbass) contribute to the fact that most of the industrial emissions of pollutants are not dispersed in the atmospheric air, but are deposited in the Kuznetsk Basin and form photochemical smog, which has a negative impact on public health. The most difficult environmental situation is noted in Novokuznetsk, Mezhdurechensk, Belovo, Polysaevo, Myski, Leninsk-Kuznetsky, Kaltan, Kemerovo, as well as in Novokuznetsky, Leninsk-Kuznetsky, Prokopyevsky and Belovo Districts. This is primarily due to location of most of the large industrial centers of the Kemerovo Region (Kuzbass), where almost two-thirds of the Kemerovo Region population reside.

In a survey of the Altai Territory and the Tomsk Region residents, 43\% of them, first of all, are depressed by the quality of water resources. State report "On State and Protection of Environment of the Russian Federation in 2019" noted that the discharge of insufficiently treated polluted wastewater in 2019 was 1,187.6 million $\mathrm{m} 3$, and the discharge of untreated polluted wastewater was 437.68 million $\mathrm{m} 3$ [3]. Difficult situation on the discharge of polluted wastewater is observed in the Kemerovo Region (Kuzbass). Enterprises of mining, fuel and energy, metallurgical, coke-chemical, chemical, woodworking industry, agroindustrial complex and municipal services pollute wastewater of the Tom River and its tributaries. It shall be noted that discharge volume of polluted sewage waters into surface water bodies has reduced from 767.1 to 432.8 million $\mathrm{m} 3$ for the last ten years, but the volume of effluents, discharged to surface water bodies, has greatly increased from 5.4 to 165.9 million $\mathrm{m} 3$ for the same period. In general, as a result of industrial enterprises' activities only $61.1 \%$ of the population of the Kemerovo Region (Kuzbass) receive good quality drinking water.

In contrast to other regions of the SFD, 59.3\% of the Irkutsk Region population expressed concern about the state of forests, and $45.8 \%$ of respondents in the Altai Republic are concerned about waste accumulation. However, it is the Altai Republic that recorded the least amount of waste generation in 2019, which amounted to 0.088 million tons. As a comparison, in the same year, the highest rate of waste generation was noted in the Kemerovo Region (Kuzbass) 3,789.596 million tons, and the total waste volume in the SFD in 2019 was 5,010.138 million tons, which exceeded the same figure for the previous year by 4\% [3]. Following the "the contaminator pays" worldwide principle of waste management it is necessary to use the received funds for carrying out environmental protection measures to restore ecology in places of accumulation of household and industrial waste [9].

The least excitement on ecological safety problems among the SFD population causes a condition of fauna and flora and a condition of soils. The SFD population, most likely, does not think about the fact that in the cities, located in the area of mining enterprises, the soil is polluted with chromium, lead, zinc, manganese and cadmium, the concentration of which in $6.1-30.5 \%$ of cases exceeded the maximum allowable concentration. In the impact zone of chemical industries, the soil of residential and suburban areas is contaminated with arsenic, phenol, methanol, formaldehyde, lead, cadmium, manganese, 3,4 benzo(a)pyrene. Near metallurgical enterprises the soil is polluted above the maximum allowable concentration with nickel chromium, lead, manganese, arsenic, fluorine, zinc and benzo(a)pyrene compounds. In the eco-economic rating for Russian regions, the list of leading SFD regions 
includes only the Altai Republic, while the Tyumen, Irkutsk and Kemerovo Regions are included in the list of outsider regions. An urgent problem of organizing the rational use of land resources is the elimination of the violation consequences of land use environmental norms as a result of coal mining, which is carried out mainly by open-pit method.

\section{Conclusion}

Ensuring environmental safety is one of the prerequisites for sustainable development. The high degree of negative impact on the SFD environment is due to such reasons as the large scale and high degree concentration of industrial facilities; industry structure, including types of industry of high hazard class (mining of minerals, metallurgical and chemical production, power generation). The development of resource-intensive industries is associated with high environmental costs. This is the land destruction as a result of coal mining, the huge industrial waste formation, environmental pollution by emissions and discharges from metallurgical, chemical, coal mining and other industrial enterprises, the biodiversity reduction in the industrially developed areas and other adverse environmental effects. The high level of environment anthropogenic load and the negative consequences of its impact on the SFD population health determine the need to increase spending on the protection and restoration of ecosystems and the implementation of measures to protect public health. In the strategic perspective the aggravation of the current trends in the region ecology can have a significant negative impact on the region attractiveness for the population, tourists and investors.

However, in the presence of serious problems that threaten the SFD environmental security, certain steps on the part of the state authorities to improve the environmental situation have been observed. For example, the national projects of the Russian Federation for the period from 2019 to 2024 include the Ecology national project, which includes 11 federal projects. The most urgent environmental problems of the SFD among them are federal projects: Clean Air; Forest Conservation; Clean Water and Unique Water Bodies Conservation; Integrated System of Solid Municipal Waste Management, Infrastructure for the Waste Management of I-II Hazard Classes and Clean Country, which provides to reduce the negative impact of accumulated waste on the environment.

The right of each citizen of the Russian Federation to the environment state contributing to his health and property preservation is fixed in Article 42 of the Constitution of the Russian Federation. The same article notes the right of citizens not only to reliable information about the environment state, but also to compensation for damage, which occurred as a result of environmental infringements. Received damage is caused by violation of human right for favorable environment and is defined as ecological damage. However, the establishment of compensable damage amount is often quite difficult due to the time delay of the negative impact of environmental offenses and their consequences. A number of authors propose to introduce preventive measures, preventing the infliction of environmental damage. But in cases when preventive measures are not so effective to maintain a high level of environmental safety, the compensation of environmental damage can be carried out through the environmental insurance organization, and one of the incentives of insurance subjects can be the norms of preferential taxation [6].

\section{Acknowledgement}

The article was prepared as part of the Integrated Research and Development Program "Pure Coal - Green Kuzbass". 


\section{References}

1. Decree of the President of the Russian Federation "On Approval of the Environmental Security Strategy of the Russian Federation for the period until 2025" dated April 19, 2017, No. 176 // Collection of Legislation of the Russian Federation. 2017. No. 17. Art. 2546.

2. Decree of the President of the Russian Federation "On Approval of the Economic Security Strategy of the Russian Federation for the period until 2030" dated May 13, 2017, No. 208 // Collection of Legislation of the Russian Federation. 2017. No. 20. Art. 2902.

3. On the State and Protection of Environment of the Russian Federation in 2019. State report. - M.: Ministry of Natural Resources of Russia; Lomonosov Moscow State University, 2020. - $1000 \mathrm{p}$.

4. List of Instructions of the President of the Russian Federation based on the meeting results of the State Council "On the Environmental Development of the Russian Federation for Future Generations" (January 24, 2017), http://www.kremlin.ru/

5. S.N. Bobylev, S.V. Solovyova, K.S. Sitkina, O.V. Kudryavtseva, Vestnik of Moscow University, Series 6, Ekonomika, 2, 21 (2018)

6. M.D. Dzhikiya, Business. Education. Law, 4 (53), 334 (2020)

7. A.D. Dmitriev, A.A. Zaitsev, S.A. Zhiltsov, Business. Education. Law., 4 (53), 63 (2020)

8. T.P. Zheltyak, Colloquium-journal, 1(13), 170 (2019)

9. E.V. Maryin, Business. Education. Law, 4 (53), 281 (2020)

10. European Environment Agency. Towards a green economy in Europe. EU environmental policy targets and objectives 2010-2050. European Environment Agency Report, No. 8/2013. 